\title{
A SUMMARY OF THE USE OF MAIZE IN NUTRITIONAL PRODUCTS FOR SPORTSPEOPLE
}

\author{
Kinga Kostrakiewicz-Gierałt \\ University of Physical Education in Kraków, Faculty of Tourism and Recreation, Poland \\ Address for correspondence: \\ Kinga Kostrakiewicz-Gierałt \\ Jana Pawła II 78 \\ 31-571 Kraków, Poland \\ E-mail: kinga.kostrakiewicz@awf.krakow.pl
}

\begin{abstract}
Ahstract The aim of the investigation was to review experimental articles and patents referring to corn-based nutritional products for sportspeople published in the period 1970-2019. Publications were searched in the ISI Web of Science and Scopus databases, as well as the Google Scholar and Google Patents internet search engines. Factorial combinations of the keywords ("Zea mays" or "maize" or "corn") and ("athlete" or "sport") were applied. Most papers and patents were published in the period 2010-2019 by researchers affiliated to the USA and China - the two largest global producers of corn. Altogether, 65 patents and 16 articles were recorded. Inventors patented food supplements based on corn-derived saccharides and proteins. Empirical articles were devoted to the impact of corn-based food products on health of sportspeople, evaluation of the impact of length of consumption on the metabolism and performance of athletes, as well the frequency of use and acceptance of nutritional products based on corn by sportspeople.

Despite growing interest in the application of corn constituents in nutritional products for sportspeople, further investigations are strongly desirable.
\end{abstract}

Key worlds corn, dietary supplements, health, kernel, nutrition

\section{Introduction}

The recent decades have seen a growing interest in the impact of plant constituents on sporting health and performance. Maize or corn (Zea mays L.) ranks third after wheat and rice as a staple food for a large proportion of the population worldwide, particularly in Asian and African countries (Sandhu, Singh, Malhi, 2007; Chaudhary, Kumar, Yadav, 2014). Numerous authors (Nuss, Tanumihardjo, 2010; Wildman, Kerksick, Campbell, 2010; Shah, Prasad, Kumar, 2016) have argued that the corn kernel is an edible and nutritive part of the plant, reporting that it contains carbohydrates, proteins, fats, as well as minerals (i.e. phosphorus, sodium, sulphur, calcium, iron, potassium, magnesium, selenium, and copper) and vitamins (C, E, K, B1, B2, B3, B5, B6, B12). Moreover, it is an essential source of various phytochemicals, such as carotenoids, phenolic compounds, and phytosterols, providing human health benefits and reducing the risk of major chronic diseases (see e.g. Lopez-Martinez et al., 2009; 
Yongfeng, Jaylin, 2016; Sheng, Li, Liu, 2018). In contrast, Q. Shao and K.V. Chin (2011) have noted disadvantages in eating corn, such as obesity.

Taking this into consideration, the application of products containing constituents from Zea mays for sportspeople seems to be a very interesting issue. A bibliographic study focusing on use of corn-derived products in a sporting diet was conducted by B.I. Sorin (2015). However, given the low state of knowledge, the aim of this study was to overview the literature on the application of corn-derived products in diet of sportspeople.

\section{Material and methods}

\section{Study species}

Maize or corn (Zea mays L.) is a tall monecious annual grass with overlapping sheaths and broad conspicuously distichous leaf blades. The plants have staminate spikelets in long spike-like racemes that form large spreading terminal panicles (tassels) and pistillate inflorescences in the leaf axils, in which the spikelets occur from 8 to 16 rows on a thickened, almost woody axis (cob). The whole structure (ear) is enclosed in numerous large foliaceous bracts and a mass of long styles (silks) protrude from the tip as a mass of silky threads (Hitchcock, Chase, 1971). Corn is wind pollinated with both self and cross pollination usually possible. The shed pollen usually remains viable for 10 to 30 minutes, or longer under favorable conditions (Coe, Nueffer, Hoisington, 1988). Following successful pollination, numerous rows of kernels appear along a rachis (cob); these mature kernels are the edible grains harvested for consumption and processing.

Although the exact origin of corn is unclear, most experts (e.g. Brown, Zuber, Darrah, Glover, 1985; Galinat, 1988; Benz, 2001; Piperno, 2011) agree that it emerged in Mesoamerica before 5000 BC. Cultivated corn derives from teosinte Zea mexicana (an ancient wild grass found in Mexico and Guatemala) and it was introduced into the Old World in the sixteenth century. During its domestication from teosinte, corn has gained many agronomically significant attributes, but it has lost the ability to survive in the wild. It has become so domesticated that seeds cannot be separated from the cob and disseminated without human intervention. Corn seeds show poor dormancy, especially in the northern ranges of the crop's distribution. Plants occasionally grow in uncultivated fields and by roadsides or occur as volunteers in cultivated crops in the year following cultivation of a corn crop.

\section{Method of publication search}

For this survey, a systematic approach was applied through a dedicated step-wise process for selecting available peer-reviewed literature sources. The authors searched for peer-reviewed original full-text articles, dissertations, and patents, about the application of soybean-derived products for sportspeople, using the ISI Web of Science (All Databases) and Scopus-indexed publications. These search engines were selected as they provide a comprehensive all-encompassing database for various interdisciplinary domains. The review focused on literature documenting the application of corn published from 1970 to 2019. More publications were sought by browsing the Google Scholar and Google Patents internet search engines. Factorial combinations of the following keywords in the searches: ("Zea mays" or "maize" or "corn") and ("athlete" or "sport") were used. The selection terms were examined from the title, abstract, and keywords of the articles. The results comprised 4104 hits from the ISI Web of Science (All Databases), 169 hits from Scopus, 5,978 from the Google Scholar internet search engine, and 2,308 hits from Google Patents on 7 September 2019. After the removal of grey literature (blog posts, reports, conference 
proceedings, and notes) from the lists of searches, we selected publications from 54 records through the ISI Web of Science, 17 through Scopus, 22 from the Google Scholar, and 93 from the Google Patents internet search engine. The abstracts were then screened for relevance and eligibility. The sole inclusion criterion for patents was their usefulness for sportspeople. The other inclusion criteria for the articles were as follows: (i) investigations are relevant to the main subject of presented review, (ii) participants are people (clinical trials), (iii) no limits in age, weight, sex, nationality and number of participants, (iv) no limits in geographical location, as well as time period of investigations, and (v) abstract in English. The exclusion criteria of the articles were as follows: (i) studies irrelevant to the main subject, (ii) investigations conducted on non-human species, (iii) repetitive publications (different parts of a single study were presented in two or more papers or studies based on a population that was part of an earlier publication), (iv) abstract written in a language other than English. Finally, the author selected publications based on the scope which resulted in 42 records through the ISI Web of Science, 10 through Scopus, 12 from Google Scholar and 56 from the Google Patents internet search engines. Following the removal of duplicates (publications indexed in at least two databases) from all searches and an initial screening of full-texts, a final total of 114 records were selected to be reviewed. The inclusion criteria of the articles were as follows: (i) observational, descriptive studies (case report/ case series), (ii) observational, analytical studies (case-control studies, cross-sectional studies, cohort

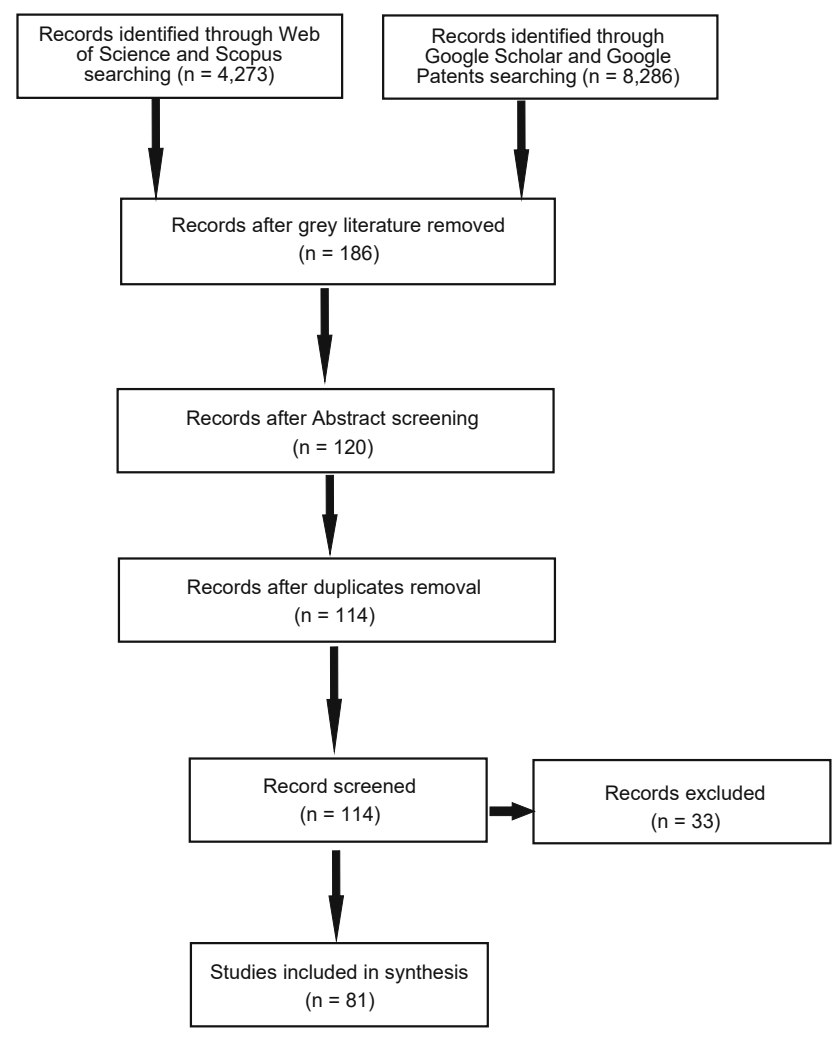

Figure 1. The simplified PRISMA flow chart detailing search results Source: after Moher, Liberati, Tetzlaff, Altman (2009). 
studies), (iii) experimental studies (randomized controlled trials). The exclusion criteria of the articles were as follows: (i) meta-analyses and (ii) systematic reviews, (iii) lack of full text, and (iv) lack of full text in English. Following the initial screening of abstracts from all the searches, a final total of 81 records were selected to be reviewed. A chart detailing the search results is presented in Figure 1. A statistical analysis based on non-parametric Kruskal-Wallis $\mathrm{H}$ test for multiple comparisons was used to check the statistical significance of differences among the numbers of records in particular decades.

\section{Results}

Most publications focusing on the application of corn-based products for sportspeople were published in the period 2010-2019 (Table 1). The authors of the majority of patents/publications are affiliated to the USA and China (Table 2). The inventors had patented food supplements (in the majority), sportswear, and devices enhancing sporting activities, while the empirical publications were devoted to nutritional products. The results of the literature survey are presented below.

Tahle 1. The number of experimental publications and patents connecting with application of corn products for sportspeople in particular time periods

\begin{tabular}{ccc}
\hline Time period (years) & Mean number of publications per year $( \pm S D)$ & The value of H Kruskal-Wallis test; $p$ value \\
\hline $1970-1979$ & $0.10( \pm 0.32)^{\mathrm{a}}$ \\
\hline $1980-1989$ & $0.20( \pm 0.42)^{\mathrm{a}}$ \\
\hline $1990-1999$ & $0.30( \pm 0.48)^{\mathrm{a}}$ & $\mathrm{H}=39.51, \mathrm{p}<0.001$ \\
\hline $2000-2009$ & $2.70( \pm 1.91)^{\mathrm{b}}$ & \\
\hline $2010-2019$ & $5.50( \pm 2.72)^{\mathrm{b}}$ & \\
\hline
\end{tabular}

The different letters ( $a$ and $b$ ) in superscripts mean that differences among time periods are statistically significant. The same letters in superscripts mean that differences among time periods are statistically insignificant.

Table 2. Geographic distribution of literature*

\begin{tabular}{lcc}
\hline \multicolumn{1}{r}{ Author affiliation } & Number of publications & Percentage \\
\hline USA & 2 & 3 \\
China & 31 & 38.2 \\
Australia & 13 & 16.2 \\
Spain & 4 & 5.0 \\
Canada & 4 & 5.0 \\
Armenia & 2 & 2.5 \\
Austria & 2 & 2.5 \\
France & 2 & 2.5 \\
Great Britain & 2 & 2.5 \\
Japan & 2 & 2.5 \\
Netherlands & 2 & 2.5 \\
Russia & 2 & 2.5 \\
Argentina & 2 & 2.5 \\
Brasil & 1 & 1.2 \\
Chile & 1 & 1.2 \\
\hline
\end{tabular}




\begin{tabular}{|c|c|c|}
\hline & 2 & 3 \\
\hline Denmark & 1 & 1.2 \\
\hline Etiopia & 1 & 1.2 \\
\hline Germany & 1 & 1.2 \\
\hline India & 1 & 1.2 \\
\hline Malaysia & 1 & 1.2 \\
\hline New Zeland & 1 & 1.2 \\
\hline Norway & 1 & 1.2 \\
\hline Sweden & 1 & 1.2 \\
\hline Switzerland & 1 & 1.2 \\
\hline UK & 1 & 1.2 \\
\hline
\end{tabular}

"In case of multi-authored publications affiliation of the first author was considered.

\section{Mono-, oligo- and polysaccharides}

Several scientists had invented a recipe for carbohydrate blends comprising extracts from maize (corn syrup) that might be used as sweeteners in sport nutrition products, such as powders, pre-mixes, juices, energy bars, isotonic drinks and gelatine, and starch-based or pectin jellies (Table 3).

Table 3. The patented recipes for carbohydrate blends comprising extracts from corn

\begin{tabular}{lccc}
\hline \multicolumn{1}{c}{ Patent } & Patent number & Inventor(s) & Year \\
\hline $\begin{array}{l}\text { Use of novel carbohydrates and carbohydrate blends } \\
\text { to provide a sports beverage with increased absorption }\end{array}$ & US20100129497A1 & V. Rinaldi, J. Zachwieja, X. Shi, Z. Ali & 2010 \\
\hline Natural sweetenter & US20150208703A1 & R. Turner & 2015 \\
\hline High carbohydrate food product & ES2603436-A1 & M.B. Sorinas & 2017 \\
\hline Sugar extracts & US9572852B2 & L.L. llag, J. Smythe, T.P. Ellis, R.S. Weisinger & 2017 \\
\hline
\end{tabular}

Source: https://patents.google.com/patent.

Most patents were devoted to methods of producing nutrient products containing high fructose corn syrup as a sweetener. Such products are represented by beverages suitable for reducing fatigue, diminishing muscle soreness, maintaining blood sugar level during exercise, improving cardiovascular function, increasing athletic performance, enhancing vitamin absorption, as well as reducing calories. Other researchers had patented energy bars used forelieving tension and supplementing energy before running, nutritious puree compositions suitable for sportspeople, as well as energy gels suitable for increasing available energy during exercise and for replenishing electrolytes that are depleted during exercise. Moreover, corn glucose syrup might also serve as an important ingredient in foods suitable for sportspeople. Also, the process of acquiring steviol glycoside mixtures with other ingredients such as corn syrup to be used as sweeteners and flavours composition, among others, in sport drinks, was patented (Table 4). 
Table 4. The patents of nutritive products for sportsman containing glucose corn syrup or high fructose corn syrup

\begin{tabular}{|c|c|c|c|c|}
\hline Patent & Patent number & Inventor(s) & Year & Source \\
\hline Beverages suitable for reducing fatigue & $\begin{array}{l}\text { CN102845801-A; } \\
\text { CN102845801-B }\end{array}$ & Y. Liu & 2013 & 2 \\
\hline Beverage suitable for reducing fatigue & CN107874054-A & Y. Zhan, Y. Yang, Y. Luo, J. Li, D. Yang, B. Wang et al. & 2018 & 2 \\
\hline $\begin{array}{l}\text { Reducing muscle soreness with } \\
\text { glucosamine compositions }\end{array}$ & US9089156B2 & V. Rinaldi, W. Racicot, J.J. Zachwieja, R. Murray & 2015 & 1 \\
\hline $\begin{array}{l}\text { Beverage maintaining blood sugar } \\
\text { level during exercise }\end{array}$ & CN105614612-A & X. Xia, Y. Yang, G. Zhang, X. Zhang & 2016 & 2 \\
\hline $\begin{array}{l}\text { Beverage improving cardiovascular } \\
\text { function }\end{array}$ & $\begin{array}{l}\text { CN103315347-A; } \\
\text { CN103315347-B }\end{array}$ & Y. Chen, M. Fu, J. Li, S. Liao, D. Tang, J. Wen et al. & 2013 & 2 \\
\hline $\begin{array}{l}\text { Performance enhancing sports } \\
\text { beverage and methods of use }\end{array}$ & US20120128815A1 & S.P. Poulos, J. Boza, R.O. Scott & 2012 & 1 \\
\hline $\begin{array}{l}\text { Athletic performance enhancing } \\
\text { beverage }\end{array}$ & US20150272196A1 & J.Ch. Anthony, K.D. Kent, B.L. Winters, H.W. Yeom & 2015 & 1 \\
\hline $\begin{array}{l}\text { Beverages containing water-soluble } \\
\text { vitamin } \mathrm{E}\end{array}$ & US20070141203A1 & P. Cook & 2007 & 1 \\
\hline $\begin{array}{l}\text { Use of erythritol and D-tagatose in diet } \\
\text { or reduced-calorie beverages and food } \\
\text { products }\end{array}$ & US20020160090A1 & $\begin{array}{l}\text { T. Lee, G. Olcese, Z. Bell, G. Roy, W. Mutilangi, } \\
\text { R. Hirs et al. }\end{array}$ & 2002 & 1 \\
\hline Energy bar as sweetener & CN107149142-A & X. Sun, J. Zhang, D. Mei & 2017 & 2 \\
\hline $\begin{array}{l}\text { Bite-size carbohydrate nutritional } \\
\text { products and methods for using same }\end{array}$ & US20090239803A1 & $\begin{array}{l}\text { M.G. Feuvrier-Roy, D.J. Leonard, A. Mittal, } \\
\text { A. Jeukendrup, A. Stellingwerff, E. Zaltas }\end{array}$ & 2009 & 1 \\
\hline $\begin{array}{l}\text { Puree compositions having specific } \\
\text { carbohydrate ratios and methods } \\
\text { for using same }\end{array}$ & US20130115329A1 & $\begin{array}{l}\text { V.D. Savant, T. Haile, F.C. Jimenez, C.M. Boice, } \\
\text { K.R. Welsh, E.S. Zaltas et al. }\end{array}$ & 2013 & 1 \\
\hline Electrolyte energy gel & US20050095271A1 & M. Mathewson & 2005 & 1 \\
\hline Encapsulated energy gel compositions & US20060280777A1 & A. Schydlowsky & 2006 & 1 \\
\hline $\begin{array}{l}\text { Food composition enriched with } \\
\text { babaçu coconut oil }\end{array}$ & BR102016026844-A2 & $\begin{array}{l}\text { F. Franca Silva, S.B. Do Desterro, } \\
\text { M. Do Carmo Lacerda Barbosa, E. Bouskela, } \\
\text { M.C. Pires Costa, R.M.T. Fernandes }\end{array}$ & 2018 & 1 \\
\hline Sustained release of nutrients in vivo & WO2010080557A1 & F. Sexton, S. Krishnan, V.K. Vendra & 2010 & 1 \\
\hline Glucosyl stevia composition & US8911971-B2 & A. Markosyan & 2014 & 1 \\
\hline $\begin{array}{l}\text { Stevia composition, production method } \\
\text { and uses }\end{array}$ & WO2016049315-A1 & A. Markosyan & 2016 & 1 \\
\hline
\end{tabular}

Source: https://patents.google.com/patent; https://apps.webofknowledge.com.

Corn starch as a main source of polysaccharides might be the basis of energy supplements, nutritive foods reducing the feeling of hunger, and overcoming the problems of rehydration after prolonged strenuous exertion. Other authors patented nutritive products balancing blood sugar levels and prebiotic combinations containing a high amylose corn starch suitable for sportspeople that diminishes the risk of gastrointestinal infection, and supports the uptake of important minerals such as calcium and magnesium (Table 5). 
Tahle 5 . The patents of products for sportspeople containing corn starch

\begin{tabular}{|c|c|c|c|c|}
\hline Patent & Patent number & Inventor(s) & Year & Source \\
\hline $\begin{array}{l}\text { Carbohydrate and medium chain } \\
\text { triglyceride gel as an energy suplement }\end{array}$ & WO1997007690A2 & R. Jones & 1997 & 1 \\
\hline High-protein pancake mix & JP2015142542-A & $\begin{array}{l}\text { T. Kiyota, K. Suzuki, Y. Morimoto, K. Kondo, } \\
\text { G. Masaoka, S. Nakano }\end{array}$ & 2015 & 1 \\
\hline $\begin{array}{l}\text { Corn starch and also corn flours } \\
\text { and food comprising this corn starch }\end{array}$ & WO2008080630A1 & C. Frohberg & 2008 & 1 \\
\hline The nutritional food & CN103549412-A & H. Xu & 2014 & 2 \\
\hline $\begin{array}{l}\text { Nutritionally balanced food or beverage } \\
\text { product }\end{array}$ & US20150017309A1 & G.W.C. Pope-Mayell, R.D. Rotherham, J.P. Rogers & 2015 & 1 \\
\hline Proficiency beverage & US7582324B2 & A.G. Blank & 2009 & 1 \\
\hline Food product with high viscosity & US7320810B2 & P. Wuersch, O. Ballevre, H. Milon, B. Sievert & 2008 & 1 \\
\hline $\begin{array}{l}\text { Heat moisture treated starch } \\
\text { for the treatment of hypoglycaemia }\end{array}$ & CA2544965C & X. Qi, R. Tester & 2005 & 1 \\
\hline Compositions and uses thereof & US8507462B2 & X. Qi, R. Tester & 2013 & 1 \\
\hline $\begin{array}{l}\text { Heat moisture treated carbohydrates } \\
\text { and uses thereof }\end{array}$ & WO2010077635A2 & S. Murali, P. Kaufman, J.S. Volek & 2010 & 1 \\
\hline Prebiotic combination products & WO2005056023A1 & J.Y. Piene & 2005 & 1 \\
\hline
\end{tabular}

Source: https://patents.google.com/patent; https://apps.webofknowledge.com.

\section{Oligopeptides, polypeptides and proteins}

Numerous researchers have patented methods of preparing protein hydrolysates, as well as a way of fractionating the nutritive proteins from plant material such as corn that could be useful in food products suitable for sportspeople during and after physical exercise (Table 6).

Tahle 6 . The patented methods of preparing corn protein hydrolysates

\begin{tabular}{|c|c|c|c|c|}
\hline Patent & Patent number & Inventor(s) & Year & Source \\
\hline Protein hydrolysates & WO2002032232A2 & V. Delest, L. Edens, J.G. Kortes, T.J-B. Naeye & 2002 & 1 \\
\hline Protein hydrolysate rich in tripeptides & US20080220470A1 & L. Edens, P.J.T. Dekker, De A.L. Roos & 2008 & 1 \\
\hline $\begin{array}{l}\text { Protein hydrolysate compositions stable } \\
\text { under acidic conditions }\end{array}$ & EP2299839A2 & $\begin{array}{c}\text { T.M. Wong, P.S. Kerr, P.S. Ghosh, J.F. Lombardi, } \\
\text { G.B. Lynglev, T. Hoff et al. }\end{array}$ & 2011 & 1 \\
\hline $\begin{array}{l}\text { The recipe for preparation of multi-nutrition } \\
\text { active polypeptide }\end{array}$ & CN103168983-A & S. Wang & 2013 & 2 \\
\hline $\begin{array}{l}\text { Protein hydrolysate compositions having } \\
\text { enhanced cck and glp-1 releasing activity }\end{array}$ & WO2012141795-A1 & $\begin{array}{l}\text { E.S. Krul, B. Tulk, M.K. Pawlik, J.F. Lombardi, } \\
\text { E. Krul, M. Pawlik et al. }\end{array}$ & 2012 & 1 \\
\hline $\begin{array}{l}\text { The recipe for preparation high-value } \\
\text { oligopeptide by hydrolyzing corn protein } \\
\text { solution }\end{array}$ & CN107760750-A & Q. Cui, Y. Wang, X. Song, Y. Feng, Y. Liu, Y. Xiao & 2018 & 2 \\
\hline Charged nutritive proteins and methods & US8809259B2 & $\begin{array}{l}\text { D.A. Berry, B.A. Boghigian, N.W. Silver, } \\
\text { G. von Maltzahn, M. Hamill, R. Chillakuru }\end{array}$ & 2013 & 1 \\
\hline
\end{tabular}

Source: https://patents.google.com/patent; https:/lapps.webofknowledge.com. 
Several researchers have invented recipes for nutritional drinks promoting recovery of fatigue and reducing the degree of injury, improving the athletic ability of teenagers, enhancing stress resistance, promoting growth of the brain and body, strengthening the physique and improving immunity, increasing bone calcium content and enhancing weight loss, supporting glucose uptake into the muscle and extending endurance during physical exercise, as well as optimizing muscle performance during exercise.

Simultaneously, other nutritional inventions worth noting are nutritive soups, chocolate for repairing body tissues, relieving physical fatigue, promoting digestion and preventing obesity, energy bars and food compositions provided in a ready-to-eat form or incorporated into a bar, chew, filling or paste suitable for sportspeople. Also, a dietary, prophylactic and functional food product suitable for sport alimentation and containing, among others, chapped grains of corn was patented. Furthermore, patents of sport nutritional supplements (provided in different forms) supporting lipolysis, promoting bone and muscle growth, as well as relieving sports fatigue, as well as enhancing recovery after physical exercise should be mentioned (Table 7). It should also be mentioned that S.A. Duvick, L.M. Pollak and P.J. White (2003) prepared a method of growing improved corn lines having high protein and/or oil content suitable for producing foods for sportspeople.

Table 7. The patents of nutritive products for sportspeople based on oligopeptides, polypeptides and proteins derived from corn

\begin{tabular}{|c|c|c|c|c|}
\hline Patent & Patent number & Inventor(s) & Year & Source \\
\hline 1 & 2 & 3 & 4 & 5 \\
\hline $\begin{array}{l}\text { Method for the formulation of a gel-format foodstuff } \\
\text { for use as a nutritional foodstuff enriched with peptides } \\
\text { and maltodextrins obtained from quinoa flour }\end{array}$ & WO2013091125A1 & $\begin{array}{c}\text { J.I. Cáceres, P. Enrione, D. Calderon, } \\
\text { F.O. Lira }\end{array}$ & 2013 & 1 \\
\hline $\begin{array}{l}\text { The sport drink promoting recovery of fatigue } \\
\text { and reducing injury degree }\end{array}$ & CN103704808-A & J. Hong, Z. Hu & 2004 & 2 \\
\hline $\begin{array}{l}\text { The sport drink improving the athletic ability } \\
\text { of teenagers, enhancing stress resistance, promoting } \\
\text { growth of the brain and body, strengthening physique } \\
\text { and improving immunity }\end{array}$ & CN108094786-A & Anonymous & 2018 & 2 \\
\hline $\begin{array}{l}\text { The sports nutrition milk tea powder increasing bone } \\
\text { calcium content and enhancing weight loss }\end{array}$ & $\begin{array}{l}\text { CN103549015-A; } \\
\text { CN103549015-B }\end{array}$ & W. Li & 2014 & 2 \\
\hline $\begin{array}{l}\text { Sports drink composition for enhancing glucose uptake } \\
\text { into the muscle and extending endurance during } \\
\text { physical exercise }\end{array}$ & US7740893B2 & R. Portman & 2010 & 1 \\
\hline Sports beverage and method of making & WO2009085928A2 & $\begin{array}{l}\text { W.L. Constantine, A.S.A. Dixon, } \\
\text { S. Kramer, M.W. Varhol }\end{array}$ & 2009 & 1 \\
\hline Method for manufacturing protein-containing drink & WO2019004271-A1 & S. Hata, M. Banno, M. Takakura & 2019 & 1 \\
\hline $\begin{array}{l}\text { The chocolate used for repairing body tissue, relieving } \\
\text { physical fatigue and removing redundant free radicals }\end{array}$ & CN103960436-A & $\begin{array}{c}\text { J. Liu, M. Zhang, Y. Zhang, Y. Wang, } \\
\text { H. Zhao }\end{array}$ & 2014 & 2 \\
\hline The energy bars & CN106108027-A & J. Ma, K. Yu, X. Liu, Y. Sun, X. Yan & 2016 & 2 \\
\hline The energy bars & IN201711014441-A & N. Yadav & 2019 & 2 \\
\hline $\begin{array}{l}\text { Composition based on quinoa and gofio, as well as } \\
\text { other components such as cocoa and rice flour }\end{array}$ & ES2564739-A1 & M. Gazmira, M. Toledo & 2016 & 1 \\
\hline $\begin{array}{l}\text { Dietary, prophylactic and functional food product } \\
\text { for sport alimentation }\end{array}$ & $\begin{array}{l}\text { RU2445797-C1; } \\
\text { RU2458538-C1 }\end{array}$ & A. Malyshev & 2012 & 1 \\
\hline The sport nutritional supplements supporting lipolysis & CN108606269-A & $\begin{array}{l}\text { B. Wang, X. Liu, G. Zheng, Y. Du, } \\
\text { L. Zhang, R. Qian }\end{array}$ & 2018 & 2 \\
\hline
\end{tabular}




\begin{tabular}{lccc}
\hline \multicolumn{1}{c}{1} & 2 & 3 & 4 \\
\hline $\begin{array}{l}\text { Composition comprising carbohydrate and peptide } \\
\text { material and its use as an energy supplement after } \\
\begin{array}{l}\text { or during physical exercise or as a metabolic nutrient } \\
\text { for oral consumption }\end{array}\end{array}$ & US6713082B2 & $\begin{array}{c}\text { L.J.C. Van Loon, } \\
\text { A.J.J. Wagenmakers, }\end{array}$ & 2004 \\
\hline $\begin{array}{l}\text { Functional food paste } \\
\text { Altered fatty-acid, protein, oil, and starch corn lines } \\
\text { and method for producing same }\end{array}$ & WO2010030944A2 EP2348891B1 & W.J.J. Hakkaart, W.H.M. Saris & 1 \\
\hline
\end{tabular}

Source: https://patents.google.com/patent; https://apps.webofknowledge.com.

\section{Other constituents}

Many authors patented methods of processing the corn grain to obtain an oil for the production of food suitable in sporting nutrition, as well as recipes for nutritional products (Table 8). Also, the Table contains patented compositions enabling increased bioavailability of carotenoids derived from corn and anthocyanin, which can be directly incorporated into food products, and a method of obtaining ferulic acid.

Table 8. The patents of nutritive products for sportspeople based on oils derived from corn

\begin{tabular}{lccc}
\hline \multicolumn{1}{c}{ Patent } & Patent number & Inventor(s) & Year \\
\hline $\begin{array}{l}\text { Process for increasing throughput of corn for oil } \\
\text { extraction }\end{array}$ & CA2562670A1 & $\begin{array}{c}\text { M. Van Houten, M.J. Beaver, A.M. Eyal, E.J. Fox, } \\
\text { J. Ingvalson, N.T. Jakel et. al. }\end{array}$ & 2005 \\
\hline $\begin{array}{l}\text { Products comprising corn oil and corn meal obtained } \\
\text { from high oil corn }\end{array}$ & WO2002014459A2 & $\begin{array}{c}\text { J.F. Ulrich, N.T. Jakel, T.T. Lohrmann, P.J. Mc Williams, } \\
\text { M.J. Tupy, M.J. Beaver et al. }\end{array}$ & 2002 \\
\hline $\begin{array}{l}\text { Products comprising corn oil and corn meal obtained } \\
\text { from high oil corn }\end{array}$ & US20040058052A1 & $\begin{array}{c}\text { J. Ulrich, N. Jakel, D. Kotowski, J. Ingvalson, } \\
\text { B. Aufdembrink, M. Tupy et al. }\end{array}$ & 2004 \\
\hline $\begin{array}{l}\text { Compositions and methods to increase } \\
\text { bioavailability of carotenoids }\end{array}$ & WO2009063333A2 & T. Eidenberger & 2009 \\
\hline Stabilized anthocyanin compositions & US8449927B2 & T. Eidenberger & 2008 \\
\hline Bioproduction of ferulic acid and uses thereof & WO2008116319A1 & S. Parakash, J. Bhathena & 2008 \\
\hline
\end{tabular}

Source: https://patents.google.com/patent.

\section{Investigations of products}

Several authors focused on the frequency and acceptance of using corn-derived food. Investigations of the frequency of using nutritive corn products by sportspeople were conducted by M. Mamo, P. Singh (2018) and A.R. Pérez, A.J.C. Andújar, C.S. Muñoz, J.J.M. Molina and M.Z. Díaz (2012). In the study by M. Mamo and P. Singh (2018), on a group of 165 male and 135 female senior runners, they showed that the frequency of eating corn was rather low. The study by A.R. Pérez et al., (2012), on a group of 27 young international elite motorcyclists, showed that the majority of them ate corn cereals at least once a day. The study by D.L. Christensen, G. van Hall and L. Hambraeus (2002), on 12 adolescent male Kalenjin runners in Kenya during a 2-week field study, determined that their energy intake was mainly derived from the vegetable sources - with corn and kidney beans as the staple food. The results of the physico-chemical, functional, nutritional and sensorial tests by V.C. Del Castillo, M. Armada and J.C. Gottifredi (1999) showed a considerable preference of supplementary sporting foods based on corn in 
comparison to commercial food. The study by Y. Carrera, R. Utrilla-Coello, A. Bello-Pérez, J. Alvarez-Ramirez and E.J. Vernon-Carter (2015) relate the extensive use of pinole (a traditional energy food based on flour obtained from toasted ground corn grains) by high performance ultra-runners, where the hydrolysis rate and in vitro digestibility of starch are greatly improved by the toasting process.

Other authors compared the metabolism and performance of sportspeople after consuming corn products and alternative nutritional foods. The investigation conducted in a group of 31 elite footballers from the Australian Football League (AFL) at the height of outdoor summer training demonstrated a better rehydration from a drink containing high amylose corn starch and glucose in comparison to other rehydration drinks (O'Connell et al. 2018). The study by A. Ahmad, N. Jusoh and R. Tengah (2019) on physiological responses and performance following subsequent repeated high intensity exercise with consumption of corn juice in a group of 17 hockey and football players, found that Zea mays juice containing carbohydrates (mainly glucose and fructose), proteins, and sodium has potential as an alternative recovery beverage to promote repeated exercise with a short rest time. The study by A.C. Snyder, L.O. Schulz and C. Foster (1989) found that the consumption of a carbohydrate supplement (made by the partial hydrolysis of corn starch) by elite speed skaters resulted in substantial increases in energy. The study by K.J. Cole, P.W. Grandjean, R.J. Sobszak and J.B. Mitchell (1993) examined the effects of incremental consumption of various carbohydrate solutions during prolonged exercise in 10 trained male cyclists, where the drinks with high fructose corn syrup provided a significantly higher level of carbohydrates in comparison to solutions containing glucose and sucrose. The study by G.A. Wallis, D.S. Rowlands, C. Shaw, R.L.P.G. Jentjens and A.E. Jeukendrup (2005) on a group of 8 trained cyclists showed that by drinking large amounts of maltodextrin and fructose during cycling exercise, exogenous carbohydrate oxidation can reach greater values than from ingesting maltodextrin alone. The study by J.B. Mitchell, W.A. Braun, F.X. Pizza and M. Forrest (2000) aimed at determining the influence of drinking solutions containing mixtures of carbohydrate types on pre-exercise glycemic response, exerciseinduced hypoglycemia, metabolic responses, and $10-\mathrm{km}$ treadmill running performance in a warm environment, on a group of 10 trained runners, found that the type of carbohydrate (high fructose corn syrup solution, glucose solution, sucrose and glucose mixture, banana with water) did not influence running performance or metabolic responses during exercise.

The study by M. Kern, N.D. Lagomarcino, L.M. Misell and V. Schuster (2000) focused on assessment of the blood lipid levels following consumption of a low-fat diet, medium-chain triacylglycerol or long-chain triacylglycerol in male endurance runners, where the long-chain triacylglycerol oil derived from corn has a positive impact on the blood profile of sportspeople. Further investigations by L.M. Misell, N.D. Lagomarcino, V. Schuster and M. Kern (2001) found that long-term consumption of medium-chain triacylglycerols (compared to corn-derived long-chain triacylglycerols) neither enhances endurance nor significantly alters performance-related metabolism in trained male runners.

Several investigations concentrated on the effect of the timing of ingestion of corn food products on the metabolism and performance of sportspeople. The study by M.D. Roberts, Ch. Lockwood, V.J. Dalbo, J. Volek and Ch.M. Kerksick (2011) on the impact of hydrothermally modified starch and maltodextrin on metabolic and hormonal responses in 9 male cyclists, found that ingestion of low-glycaemic hydrothermally modified starch before prolonged cycling exercise blunted the initial spike in serum glucose and insulin, and increased the breakdown in fat compared to maltodextrins. The study by R.B. Parks, H.F. Angus, D.S. King and R.L. Sharp (2018) aimed to characterize the metabolic response from consumption of modified amylomaize or dextrose before exercise, 
showing that consumption in the hour before exercise of corn-derived starch modified by partial hydrolysis (compared to dextrose consumption) resulted in a more stable serum glucose concentration, but it did not offer a performance advantage in the high-intensity cycling trial. The study by M.G. Flynn et al. (1987) examined the influence of carbohydrate consumption on exercise performance and muscle glycogen use, in a group of 8 welltrained male cyclists, demonstrating a greater blood glucose level at $90 \mathrm{~min}$ after consumption of high fructose corn syrup compared to consumption of artificially sweetened water, maltodextrin and fructose.

\section{Discussion}

Most publications focusing on the use of corn-based products by sportspeople were published in the period 2010-2019, and mainly by researchers affiliated to the USA and China. Such a phenomenon might be linked to the largest global producers of corn as noted by the two specific countries (USDA, 2019). The investigated studies have shown that the numerous beneficial constituents of corn are widely applied in the production of nutritional food. At the same time, it should be noted that there is a discrepancy in the evaluation of the influence of high fructose corn syrup on people's health. Numerous researchers (see e.g. Bray, Nielsen, Popkin, 2004; Morrill, Chinn, 2004; Bocarsly, Powell, Avena, Hoebel, 2010) link the consumption of high fructose corn syrup with increased obesity and metabolic disorders, while many scientists (see e.g. Klurfeld, Foreyt, Angelopoulos, Rippe, 2013 and literature cited herein) have highlighted a lack of evidence of high fructose corn syrup as a cause of obesity. Additionally, J.J. Johnson and R. Murray (2010) argued that for sportspeople, a positive aspect of fructose metabolism is that in combination with other simple sugars, fructose stimulates rapid fluid and solute absorption in the small intestine and helps increase exogenous carbohydrate oxidation during exercise - an important response for improving exercise performance. The aforementioned authors observed that additional research is required to clarify the possible health-related implications of a long-term intake of large amounts of dietary fructose among sportspeople.

\section{Conclusions}

Most publications focusing on the application of corn-based products by sportspeople were published between 2010 and 2019, and mainly by researchers affiliated to research centers USA and China. Inventors have patented food supplements containing mostly corn derived saccharides and proteins. Despite a substantial number of empirical articles testing the quality and social acceptance of products, further investigations seem to be strongly desirable.

\section{Acknowledgements}

The investigations were financially supported by the University of Physical Education in Krakow, where I am affiliated.

\section{References}

Ahmad, A., Jusoh, N., Tengah, R. (2019). Acute physiological responses and performance following subsequent CrossFit 'CINDY' workout with Zea Mays juice. Physical Education of Students, 23 (2), 57-63. DOI: 10.15561/20755279.2019.0201.

Benz, B.F. (2001). Archaeological evidence of teosinte domestication from Guilá Naquitz, Oaxaca. PNAS, 98 (4), 2104-2106. DOI: 10.1073/pnas.98.4.2104. 
Bocarsly, M.E., Powell, E.S., Avena, N.M., Hoebel, B.H. (2010). High-fructose corn syrup causes characteristics of obesity in rats: increased body weight, body fat and triglyceride levels. Pharmacology Biochemistry and Behavior, 97 (1), 101-106. DOI: 10.1016/j.pbb.2010.02.012.

Bray, G.A., Nielsen, S.J., Popkin, B.M. (2004). Consumption of high-fructose corn syrup in beverages may play a role in the epidemic of obesity. The American Journal of Clinical Nutrition, 79, 537-543.

Brown, W.L., Zuber, M.S., Darrah, L.L., Glover, D.Y. (1985). Origin, adaption, and types of corn. In: H.A. Wadsworth (ed.), National corn handbook. Ames, lowa: lowa State University, Cooperative Extension Service.

Carrera, Y., Utrilla-Coello, R., Bello-Pérez, A., Alvarez-Ramirez, J., Vernon-Carter, E.J. (2015). In vitro digestibility, crystallinity, rheological, thermal, particle size and morphological characteristics of pinole, a traditional energy food obtained from toasted ground maize. Carbohydrate Polymers, 123 (5), 246-255. DOI: 10.1016/j.carbpol.2015.01.044.

Chaudhary, D.P., Kumar, S., Yadav, O.P. (2014). Nutritive Value of Maize: Improvements, Applications and Constraints. In: D. Chaudhary, S. Kumar, S. Langyan (eds), Maize: Nutrition Dynamics and Novel Uses (pp. 3-17). New Delhi: Springer.

Christensen, D.L., van Hall, G., Hambraeus, L. (2002). Food and macronutrient intake of male adolescent Kalenjin runners in Kenya. British Journal of Nutrition, 88 (6), 711-717. DOI: 10.1079/BJN2002728.

Coe, E.H. Jr., Nueffer, M.G., Hoisington, D.A. (1988). The genetics of maize. In: G.F. Sprague, J.W. Dudley (eds), Corn and corn improvement. Agronomy Monographs Vol. 18 (pp. 81-236). Madison, Wisconsin: American Society of Agronomy.

Cole, K.J., Grandjean, P.W., Sobszak, R.J., Mitchell, J.B. (1993). Effect of carbohydrate-composition on fluid balance, gastric-emptying, and exercise performance. International Journal of Sport Nutrition, 3 (4), 408-417. DOI: 10.1123/ijsn.3.4.408.

Del Castillo, V.C., Armada, M., Gottifredi, J.C. (1999). A supplementary sportmen food formulation and characterization. Archivos Latinoamericanos De Nutricion, 49 (1), 61-66.

Duvick, S.A., Pollak, L.M., White, P.J. (2003). Altered fatty-acid, protein, oil, and starch corn lines and method for producing same. Patent Number: US6639132B1. Retrieved from: https://patents.google.com/patent (13.10.2019).

Flynn, M.G., Costill, D.L., Hawley, J.A., Fink, W.J., Neufer, P.D., Fielding, R.A., Sleeper, M.D. (1987). Influence of selected carbohydrate drinks on cycling performance and glycogen use. Medicine and Science in Sports and Exercise, 19 (1), 37-40.

Galinat, W.C. (1988). The origin of corn. In: G.F. Sprague, J.W. Dudley (eds), Corn and corn improvement. Agronomy Monographs Vol. 18 (pp. 1-31). Madison, Wisconsin: American Society of Agronomy.

Hitchcock, A.S., Chase, A. (1971). Manual of the grasses of the United States. New York: Dover Publications.

https://apps.webofknowledge.com (13.10.2019).

https://patents.google.com/patent (13.10.2019).

Johnson, J.J., Murray, R. (2010). Fructose, Exercise, and Health. Current Sports Medicine Reports, 9 (4), 253-258. DOI: 10.1249/ JSR.0b013e3181e7def4.

Kern, M., Lagomarcino, N.D., Misell, L.M., Schuster, V. (2000). The effect of medium-chain triacylglycerols on the blood lipid profile of male endurance runners. Journal of Nutritional Biochemistry, 11 (5), 288-292.

Klurfeld, D.M., Foreyt, J., Angelopoulos, T.J., Rippe, J.M. (2013). Lack of evidence for high fructose corn syrup as the cause of the obesity epidemic. International Journal of Obesity, 37 (6), 771-773. DOI: 10.1038/ijo.2012.157.

Lopez-Martinez, L.X., Oliart-Ros, R.M., Valerio-Alfaro, G., Lee, C.H., Parkin, K.L., Garcia, H.S. (2009). Antioxidant activity, phenolic compounds and anthocyanins content of eighteen strains of Mexican maize. LWT - Food Science and Technology, 42, 11871192. DOI: 10.1016/j.Iwt.2008.10.010.

Mamo, M., Singh, P. (2018). Nutritional intake practices of Ethiopian runners. International Journal of Academic Research and Development, 3 (2), 1548-1551.

Misell, L.M., Lagomarcino, N.D., Schuster, V., Kern, M. (2001). Chronic medium-chain triacylglycerol consumption and endurance performance in trained runners. Journal of Sports Medicine and Physical Fitness, 41 (2), 210-215.

Mitchell, J.B., Braun, W.A., Pizza, F.X., Forrest, M. (2000). Pre-exercise carbohydrate and fluid ingestion: Influence of glycemic response on 10-km treadmill running performance in the heat. Journal of Sports Medicine and Physical Fitness, 40 (1), 41-50.

Moher, D., Liberati, A., Tetzlaff, J., Altman, D.G., The PRISMA Group (2009). Preferred Reporting Items for Systematic Reviews and Meta-Analyses: The PRISMA Statement. PLoS Med, 6 (7), e1000097. DOI: 10.1371/journal.pmed100009.

Morrill, A.C., Chinn, C.D. (2004). The obesity epidemic in the United States. Journal of Public Health Policy, 25, 353-366. DOI: 10.1057/ palgrave.jphp.3190035. 
Nuss, E.T., Tanumihardjo, S.A. (2010). Maize: A paramount staple crop in the context of global nutrition. Comprehensive Reviews in Food Science and Food Safety, 9, 417-436. DOI: 10.1111/j.1541-4337.2010.00117.x.

O'Connell, S.M., Woodman, R.J., Brown, I.L., Vincent, D.J., Binder, H.J., Ramakrishna, B.S., Young, G.P. (2018). Comparison of a sportshydration drink containing high amylose starch with usual hydration practice in Australian rules footballers during intense summer training. Journal of The International Society of Sports Nutrition, 15, Article Number 46. DOI: 10.1186/s12970-018-0253-8.

Parks, R.B., Angus, H.F., King, D.S., Sharp, R.L. (2018). Effect of preexercise ingestion of modified amylomaize starch on glycemic response while cycling. International Journal of Sport Nutrition and Exercise Metabolism, 28 (1), 82-89.

Pérez, M.A.R., Andújar, A.J.C., Muñoz, C.S., Molina, J.J.M., Díaz, M.Z. (2012). Feeding habits of young international elite motorcyclists. Revista Internacional de Medicina y Ciencias de la Actividad Física y el Deporte, 12 (46), 195-207.

Piperno, D.R. (2011). The Origins of Plant Cultivation and Domestication in the New World Tropics: Patterns, Process, and New Developments. Current Anthropology, 52 (S4): 453-S470. DOI: 10.1086/659998.

Roberts, M.D., Lockwood, Ch., Dalbo, V.J., Volek, J., Kerksick, Ch.M. (2011). Ingestion of a high-molecular-weight hydrothermally modified waxy maize starch alters metabolic responses to prolonged exercise in trained cyclists. Nutrients, 27 (6), 659-665. DOI: 10.1016/j.nut.2010.07.008.

Sandhu, K.S., Singh, N., Malhi, N.S. (2007). Some properties of corn grains and their flours I: Physicochemical, functional and chapatimaking properties of flours. Food Chemistry, 101, 938-946. DOI: 10.1016/j.foodchem.2006.02.040.

Shah, T.R., Prasad, K., Kumar, P. (2016). Maize - A potential source of human nutrition and health: A review. Cogent Food \& Agriculture, 2 (1), 1166995. DOI: 10.1080/23311932.2016.1166995.

Shao, Q., Chin, K-V. (2011). Survey of American food trends and the growing obesity epidemic. Nutrition Research and Practice, 5 (3), 253-259. DOI: 10.4162/nrp.2011.5.3.253.

Sheng, S., Li, T., Liu, R.H. (2018). Corn phytochemicals and their health benefits. Food Science and Human Wellness, 7 (3), $185-195$. DOI: 10.1016/j.fshw.2018.09.003.

Smith, W.C., Brown, J.A., Holt, S.K. (2010). Functional food paste. Patent Number: WO2010030944A2; EP2348891B1. Retrieved from: https://patents.google.com/patent (13.10.2019)

Snyder, A.C., Schulz, L.O., Foster, C. (1989). Voluntary consumption of a carbohydrate supplement by elite speed skaters. Journal of the American Dietetic Association, 89 (8), 1125-1127.

Sorin, B.I. (2015). Study on the use of cereal and vegetable in the diet of athletes. Scientific Papers. Series D. Animal Science, 58, 97-99.

Tang, X. (2019). Breathable antibacterial sport shoe, has warp yarn formed by chitosan fiber and copper ion fiber, weft yarn fixed with maize fiber and bamboo fiber, and sole formed with through hole from outer side to inner side along downwards direction. Patent Number: CN109393641-A. Retrieved from: https://apps.webofknowledge.com (13.10.2019).

USDA (2009). World Agricultural Production. Foreign Agricultural Service/USDA Office of Global Analysis. Retrieved from: https://apps. fas.usda.gov/psdonline/circulars/production.pdf (13.10.2019).

Wallis, G.A., Rowlands, D.S., Shaw, C., Jentjens, R.L.P.G., Jeukendrup, A.E. (2005). Oxidation of combined ingestion of maltodextrins and fructose during exercise. Medicine and Science in Sports and Exercise, 37 (3), 426-432.

Wildman, R., Kerksick, C., Campbell, B. (2010). Carbohydrates, Physical Training, and Sport Performance. Strength and Conditioning Journal, 32 (1), 21-29. DOI: 10.1519/SSC.0b013e3181bdb161.

Yongfeng, A., Jaylin, J. (2016). Macronutrients in Corn and Human Nutrition. Comprehensive Reviews in Food Science and Food Safety, 15 (3), 581-598. DOI: 10.1111/1541-4337.12192.

Cite this anticle aS: Kostrakiewicz-Gierałt, K. (2020). A Summary of the Use of Maize in Nutritional Products for Sportspeople. Central European Journal of Sport Sciences and Medicine, 3 (31), 33-45. DOI: 10.18276/cej.2020.3-03. 